\title{
Pengaruh Pendidikan Kewirausahaan dan Dukungan Akademik Terhadap Niat Kewirausahaan Mahasiswa (Studi Pada Mahasiswa STIEPARI Semarang)
}

\author{
Aurilia Triani Aryaningtyas ${ }^{1)^{*}}$, Dyah Palupiningtyas ${ }^{2)}$ \\ Program Studi Manajemen, Sekolah Tinggi Ilmu Ekonomi Pariwisata Indonesia (STIEPARI) \\ Jl. Lamongan Raya no. 11 Semarang, Indonesia \\ *Email: aurilia.ta@gmail.com
}

\begin{tabular}{|c|c|}
\hline ARTICLE INFO & ABSTRAK \\
\hline $\begin{array}{c}\text { Received: } \\
\text { 30 Agustus } 2017 \\
\text { Revised: } \\
\text { 11 September } 2017 \\
\text { Accepted: } \\
\text { 25 Oktober } 2017\end{array}$ & $\begin{array}{l}\text { Tujuan dari penelitian ini untuk menganalisis pengaruh pendidikan kewirausahaan dan } \\
\text { dukungan akademik terhadap niat kewirausahaan mahasiswa. Data dari } 68 \text { mahasiswa } \\
\text { STIEPARI Semarang digunakan untuk menguji model hipotesis. Penelitian menggunakan } \\
\text { teknik saturation sampling dan pengumpulan data dengan kuisioner. Teknik analisis data } \\
\text { yang digunakan adalah regresi linear berganda. Hasil menunjukkan bahwa pendidikan } \\
\text { kewirausahaan dan dukungan akademik secara positif dan signifikan berpengaruh terhadap } \\
\text { niat kewirausahaan mahasiswa. Implikasi teoritis atas hasil penelitian mendukung teori } \\
\text { maupun penelitian yang sudah ada. Selain itu, implikasi manajerial atas hasil penelitian } \\
\text { menyarankan pada lembaga pendidikan untuk mempertimbangkan pendidikan } \\
\text { kewirausahaan dan dukungan akademik sebagai faktor yang cukup penting untuk } \\
\text { mendorong minat mahasiswa dalam berwirausaha. }\end{array}$ \\
\hline
\end{tabular}

Kata Kunci: Dukungan akademik, Niat kewirausahaan, Pendidikan kewirausahaan.

\section{The influence of entrepreneurship education and academic support on student entrepreneurial intentions (the study on STIEPARI Semarang Student)}

\begin{abstract}
The purpose of this research is to analyze the influence of entrepreneurship education and academic support on entrepreneurial intentions of college students. Data from 68 students STIEPARI Semarang is used to test the hypothesized model. Research using saturation sampling techniques and data was collected by questionnaire. The analysis technique used in this research is multiple linear regression. The results showed that entrepreneurship education and academic support in a positive and significant effect on entrepreneurial intentions of college students. Theoretical implications of the results of research supports the theory and existing research. In addition, managerial implications of the results of research suggest the educational institutions to consider entrepreneurship education and academic support as a factor that is important enough to encourage student interest in entrepreneurship.
\end{abstract}

Keywords: Locus of Control, Job Stress, Performance.

How to cite:

Aurilia Triani Aryaningtyas, T. A., dan Palupiningtyas, D. Pengaruh Pendidikan Kewirausahaan dan Dukungan Akademik Terhadap Niat Kewirausahaan Mahasiswa (Studi Pada Mahasiswa STIEPARI Semarang). Jurnal Ilmiah Manajemen \& Bisnis, 


\section{IT

\section{PENDAHULUAN}

Masalah

ketenagakerjaan, pengangguran, dan kemiskinan sudah menjadi masalah pokok bangsa Indonesia dan membutuhkan penanganan segera supaya tidak semakin membelit dan menghalangi langkah Indonesia untuk menjadi negara yang lebih maju. Langkah pemerintah untuk membuka banyak lapangan kerja baru sepertinya tidak banyak membantu mengurangi jumlah pengangguran di Indonesia. Demikian pula berbagai upaya yang telah dilakukan pemerintah untuk menurunkan jumlah penduduk miskin dengan memberikan fasilitas rusunawa, memberikan BLT (Bantuan Langsung Tunai), hingga pemberian aneka subsidi untuk masyarakat miskin kelihatannya juga belum mampu membuat jumlah penduduk miskin di Indonesia menjadi berkurang (Listyaningsih dan Kiswanto, 2009).

Dalam rangka menghadapi era perdagangan bebas, kita ditantang bukan hanya untuk mempersiapkan Sumber Daya Manusia yang siap bekerja, melainkan juga harus mampu mempersiapkan dan membuka lapangan kerja baru. Saat ini jumlah lapangan kerja sangat terbatas dan tidak mampu mengimbangi laju pertumbuhan penduduk Indonesia terutama usia produktif. Penganggguran di setiap jenjang pendidikan sudah semakin parah dan perlu segera dicari pemecahannya melalui penciptaan lapangan kerja di berbagai sektor usaha. Laporan International Labor Organization (ILO) mencatat jumlah pengangguran terbuka pada tahun 2009 di Indonesia berjumlah 9.6 juta jiwa (7.6\%), dan $10 \%$ diantaranya adalah sarjana (Nasrun, 2010). Dengan demikian menjadi wirausahawan pada saat ini sangat diperlukan, tidak hanya untuk kepentingan diri sendiri, tetapi yang lebih penting dan mendesak adalah untuk mengabdi kepada bangsa dan negara dengan menciptakan lapangan kerja bagi orang lain.

Mahasiswa sebagai salah satu golongan elit masyarakat yang diharapkan menjadi pemimpin-pemimpin bangsa masa depan, sudah sepantasnya menjadi pelopor dalam mengembangkan semangat kewirausahaan. Lulusan perguruan tinggi harus berani memulai usaha agar tidak bergantung pada lapangan pekerjaan yang jumlahnya terbatas. Ada 360 ribu orang sarjana yang masih menganggur dari total pengangguran sebanyak 7,17 juta orang (Dani, 2013). Jika setiap sarjana yang menganggur itu mampu mandiri dengan berwirausaha maka akan mengurangi jumlah pengangguran. Apalagi jika pengusaha muda itu mampu memperkerjakan satu orang karyawan saja, hal ini akan sangat membantu mengurangi beban pemerintah dalam hal mengatasi pengangguran. Dengan demikian perekonomian Indonesia akan terus bergerak maju dan bukan hal yang mustahil kita bangkit menjadi bangsa yang besar.

Berdasar hal-hal yang telah dikemukakan di atas, maka perguruan tinggi bertanggung jawab dalam mendidik dan memberikan kemampuan wirausaha kepada para lulusannya dan memberikan motivasi untuk berani memilih berwirausaha sebagai karir mereka. Pihak perguruan tinggi perlu menerapkan pola pembelajaran kewirausahaan yang kongkrit berdasar masukan empiris untuk membekali mahasiswa dengan pengetahuan yang bermakna agar dapat mendorong semangat mahasiswa untuk berwirausaha (Yohnson, 2003; Wu dan Wu, 2008).

Persoalannya bagaimana menumbuhkan motivasi berwirausaha yang efektif di kalangan mahasiswa dan faktor-faktor apa yang berpengaruh terhadap niat mahasiswa untuk memilih karir berwirausaha setelah 


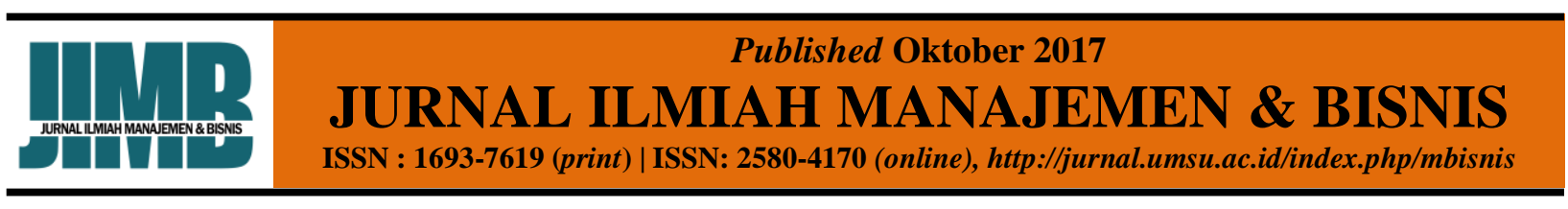

mereka lulus perguruan tinggi. Di sinilah pentingnya pendidikan kewirausahaan yang diharapkan dapat memberikan bekal pengetahuan kewirausahaan di kalangan mahasiswa. Pendidikan kewirausahaan diharapkan memberikan landasan teoritis tentang konsep kewirausahaan, membentuk pola pikir, sikap, dan perilaku seorang wirausahawan (Nursito dan Nugroho, 2013).

Sekolah Tinggi Ilmu Ekonomi Pariwisata Indonesia (STIEPARI) sebagai salah satu perguruan tinggi swasta di Semarang yang ikut bertanggung jawab dalam mendidik dan memberikan kemampuan wirausaha serta memberikan motivasi bagi mahasiswa untuk berani memilih berwirausaha sebagai karir mereka.Untuk itu STIEPARI Semarang telah membekali mahasiswanya untuk menjadi wirausaha dengan memberikan pendidikan kewirausahaan melalui mata kuliah kewirausahaan yang diberikan pada mahasiswa Program Diploma 3, Strata 1 maupun Program Pascasarjana. Melalui mata kuliah kewirausahaan ini, diharapkan dapat membuat mahasiswa memiliki mental berwirausaha serta mampu menumbuhkan minat untuk menjadi wirausaha yang sesungguhnya setelah mereka diwisuda.

Menurut Kalla (2011), pendidikan penting untuk mempersiapkan calon wirausahawan, namun demikian pendidikan tidak serta merta akan melahirkan seorang wirausahawan. Hal ini menunjukkan bahwa terdapat faktor lain yang mempengaruhi intensi kewirausahaan. Secara teori diyakini bahwa pembekalan pendidikan kewirausahaan pada seseorang sejak usia dini dapat meningkatkan potensi seseorang untuk menjadi wirausahawan. Beberapa penelitian menunjukkan hasil yang mendukung pernyataan tersebut (Kourilsky dan Walstad, 1998; Gerry et al., 2008). Beberapa penelitian juga telah menemukan bahwa pendidikan kewirausahaan berpengaruh secara signifikan terhadap minat berwirausaha (Noel, 1998; Lestari dan Wijaya, 2012; Wilson, et al., 2007).

Namun selain pendidikan kewirausahaan, ada faktor lain yang diduga juga merupakan kontekstual yang berpengaruh terhadap niat kewirausahaan yaitu dukungan pihak akademik (academic support) (Gurbuz dan Aykol, 2008). Literatur kewirausahaan membahas adanya faktorfaktor kontekstual yang membentuk niat berwirausaha seseorang. Dalam dunia mahasiswa dan perguruan tinggi sebagai penyelenggara pendidikan kewirausahaan, faktor kontekstual ini diterjemahkan sebagai faktor lingkungan diperguruan tinggi yang dapat mempengaruhi intensi berwirausaha pada mahasiswa, meliputi situasi ekonomi, politik, dan budaya di sebuah negara, kompleksitas administratif, akses terhadap sumber daya, serta infrastruktur fisik dan institusional (Indarti, 2004). Sejumlah penelitian juga membuktikan bahwa academic support, social support, dan environmental support mempengaruhi intensi siswa untuk memulai suatu usaha baru (Galloway, et al., 2006; Rasheed, 2000; Suharti dan Sirene, 2011).

Oleh karena itu, maka penelitian ini bertujuan menguji pengaruh faktor pendidikan kewirausahaan dan dukungan pihak akademik terhadap niat kewirausahaan mahasiswa STIEPARI Semarang, sehingga diharapkan dapat memberikan masukan empiris bagi pengembangan kerangka pembelajaran pendidikan kewirausahaan yang lebih kongkrit dalam rangka mendorong munculnya lulusan yang memilih karir sebagai entrepreneur. 


\section{Published Oktober 2017}

\section{KAJIAN TEORITIS}

Niat Kewirausahaan

\section{Intention)}

Niat kewirausahaan individu merupakan variabel penting untuk memprediksi perilaku kewirausahaan mereka. Niat kewirausahaan dapat diartikan sebagai langkah awal dari suatu proses pendirian sebuah usaha yang umumnya bersifat jangka panjang (Lee dan Wong, 2004). Menurut Krueger (1993), niat kewirausahaan mencerminkan komitmen seseorang untuk memulai usaha baru dan merupakan isu sentral yang perlu diperhatikan dalam memahami proses kewirausahaan pendirian usaha baru. Menurut Rasli, et al., (2013), niat kewirausahaan adalah suatu pikiran yang mendorong individu untuk menciptakan usaha.

Intensi (niat) berwirausaha merupakan prediksi yang dapat dipercaya untuk mengukur perilaku kewirausahaan dan aktivitas kewirausahaan (Krueger, et al., 2000). Umumnya, intensi berwirausaha adalah keadaan berfikir yang secara langsung dan mengarahkan perilaku individu ke arah pengembangan dan implementasi konsep bisnis yang baru (Narzudin, et al., 2009). Dengan demikian, dapat disimpulkan bahwa intensi berwirausaha adalah niat seseorang untuk mendirikan suatu bisnis atau menerapkan konsep bisnis yang belum ada dengan sesuatu yang baru.

Seseorang dengan intensi untuk memulai suatu usaha akan memiliki kesiapan dan kemajuan yang lebih baik dalam usaha yang dijalankan dibandingkan seseorang tanpa intensi untuk memulai usaha. Manifestasi dari hal tersebut ditunjukkan dalam kemauan yang keras untuk memilih kewirausahaan sebagai pilihan pekerjaan dan mempersiapkan diri untuk mewujudkannya. Oleh karena itu, menurut Choo dan Wong (2006), melalui intensi kewirausahaan dapat diprediksi individu mana saja yang akan menjadi wirausahawan.

Menurut Suharti dan Sirene (2011), faktor-faktor yang berpengaruh terhadap niat kewirausahaan mahasiswa antara lain: Faktor sosio demografi, yang meliputi : gender, bidang studi, pekerjaan orang tua, dan pengalaman berwirausaha; Faktor sikap (attitude), yang meliputi : Autonomy dan authority, Economic opportunity dan challenge, Security dan workload, Avoid responsibility, Self realization dan participation, Social environment, dan Perceived confidence; Faktor kontekstual, yang meliputi : pendidikan kewirausahaan, Academic support, Social support, dan Environmental support.

Indikator niat kewirausahaan menurut Gerry, et al., (2008) terdiri atas beberapa hal yaitu: Akan memilih karir sebagai wirausahawan setelah lulus nanti; Lebih suka menjadi wirausahawan dalam usaha sendiri daripada menjadi karyawan suatu perusahaan/ organisasi; dan Memperkirakan dapat memulai usaha sendiri (berwirausaha) dalam 1-3 tahun kedepan.

\section{Pendidikan Kewirausahaan}

Pendidikan kewirausahaan merupakan suatu disiplin ilmu yang mempelajari nilai, kemampuan dan perilaku dalam menghadapi berbagai tantangan hidup. Pendidikan kewirausahaan diajarkan sebagai suatu disiplin ilmu karena kewirausahaan memiliki badan pengetahuan yang utuh dan nyata, memiliki dua konsep yaitu venture start-up dan venture growth serta memiliki objek tersendiri yaitu kemampuan menciptakan sesuatu (Suryana, 2006). Lestari dan Wijaya (2012) menyatakan bahwa pendidikan kewirausahaan secara langsung dapat mengubah pola pikir, sikap, dan perilaku pada mahasiswa untuk menjadi wirausaha 


\section{$\frac{10}{3}$}

Published Oktober 2017

JURNAL ILMIAH MANAJEMEN \& BISNIS

ISSN : 1693-7619 (print) | ISSN: 2580-4170 (online), http://jurnal.umsu.ac.id/index.php/mbisnis

yang nantinya dapat mengarahkan mereka untuk memilih berwirausaha sebagai pilihan karir.

Menurut Lestari dan Wijaya (2012), faktor-faktor yang berpengaruh terhadap pendidikan kewirausahaan adalah: Pembentukan pola pikir mahasiswa untuk menjadi seorang wirausahawan (entrepreneur) sejati; Pembentukan sikap mahasiswa untuk menjadi seorang wirausahawan (entrepreneur) sejati; Pembentukan perilaku mahasiswa untuk menjadi seorang wirausahawan (entrepreneur) sejati.

Menurut Budiarti (2012) dan Bukirom, et al., (2014), untuk mengukur variabel pendidikan kewirausahaan dapat dilakukan dengan beberapa indikator yaitu: Program pendidikan kewirausahaan tumbuhkan keinginan berwirausaha; Program pendidikan kewirausahaan menambah ilmu dan wawasan dalam bidang wirausaha; Program pendidikan kewirausahaan tumbuhkan kesadaran adanya peluang bisnis.

\section{Dukungan Akademik}

Menurut Bandura (Alwisol, 2009), dukungan akademik mengacu pada faktorfaktor yang berkaitan dengan dukungan bagi seorang pelajar untuk mencapai dan menyelesaikan tugas-tugas studi dengan target hasil dan waktu yang telah ditentukan. Sementara itu menurut Peraturan Pemerintah No. 60 Tahun 1999, kebebasan akademik merupakan kebebasan yang dimiliki oleh anggota sivitas akademika untuk melaksanakan kegiatan yang terkait dengan pendidikan dan pengembangan ilmu pengetahuan dan teknologi secara bertanggung jawab dan mandiri. Dalam kaitannya dengan dukungan akademik, kebebasan akademik merupakan implementasi bentuk dukungan akademik pada mahasiswa.
Menurut Autio, et al., (2001), faktorfaktor yang berpengaruh terhadap dukungan akademik antara lain: Dukungan untuk memulai usaha sendiri; Dorongan untuk mengeluarkan ide-ide; Tersedia dukungan infrastruktur yang baik untuk praktek pendirian usaha.

Indikator dukungan akademik menggunakan skala dari Autio, et al., (2001), yang juga digunakan dalam Gurbuz dan Aykol (2008) yaitu: Tahu beberapa orang di kampus yang sukses berwirausaha (memulai usaha mereka sendiri); Orang secara aktif didorong untuk mengeluarkan ide-ide mereka sendiri di kampus; Bertemu dengan banyak orang di kampus, yang memiliki ide bagus untuk memulai usaha baru (berwirausaha); Tersedia dukungan infrastruktur yang baik untuk praktek pendirian usaha baru di di kampus.

Berdasarkan tinjauan literatur di atas, maka dikembangkan model penelitian yang digambarkan dalam bagan berikut:

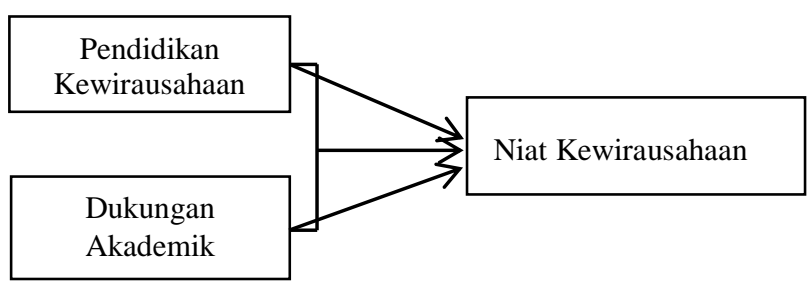

Gambar 1. Kerangka Konseptual

Berdasarkan kerangka berpikir dalam kajian teoritis di atas, maka dirumuskan beberapa hipotesis yang akan diuji dalam penelitian ini: (1) Pendidikan kewirausahaan berpengaruh terhadap niat kewirausahaan mahasiswa. (2) Dukungan akademik berpengaruh terhadap niat kewirausahaan mahasiswa. (3) Pendidikan kewirausahaan dan dukungan akademik secara bersama-sama 


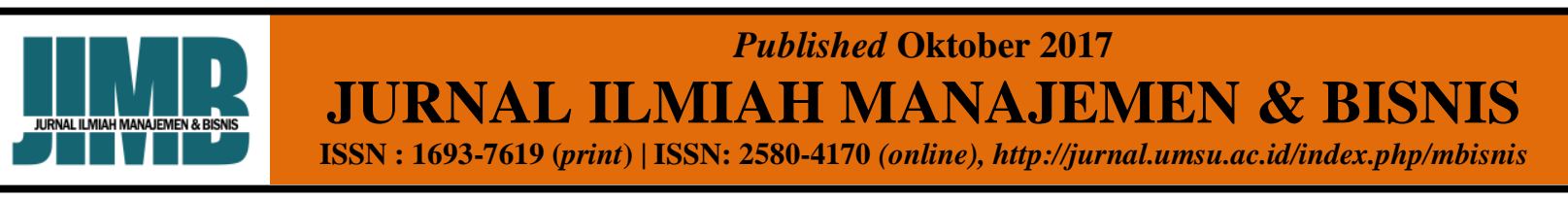

berpengaruh terhadap niat kewirausahaan mahasiswa.

\section{METODE}

Penelitian ini menggunakan pendekatan penelitian eksplanatoris (explanatory research). Populasi dalam penelitian ini adalah seluruh mahasiswa Program Diploma 3 semester enam reguler dan Strata 1 semester enam dan delapan reguler STIEPARI Semarang yang masih aktif kuliah pada semester genap tahun 2014/2015. Total berjumlah 76 orang. Adapun alasan pemilihan populasi adalah bahwa mahasiswa tersebut sudah pernah mengikuti mata kuliah kewirausahaan. Selain itu mahasiswa Program Diploma 3 dan Strata 1 reguler STIEPARI Semarang sebagian besar belum bekerja secara tetap. Teknik sampling yang digunakan adalah saturation sampling, dimana diusahakan untuk mendapatkan data dari seluruh anggota populasi yang ada. Pengumpulan data dalam penelitian ini dilakukan dengan penyebaran kuesioner terstruktur. Kuesioner sebanyak 76 set namun yang kembali sebanyak 68 set dan semuanya terisi lengkap serta layak digunakan dalam analisis data. Profil responden secara umum didominasi oleh mereka yang berjenis kelamin laki-laki $(54,4 \%)$, Program S1 $(77,9$ $\%)$, Orang tua tidak berwirausaha $(57,4 \%)$, dan pernah berpengalaman berwirausaha $(51,5 \%)$.

Dalam penelitian ini, data primer diperoleh dengan menggunakan kuesioner penelitian terstruktur, yang terbagi dalam 3 bagian: pendidikan kewirausahaan, dukungan akademik dan niat kewirausahaan. Dalam pengukuran variabel pendidikan kewirausahaan, responden diminta untuk menjawab 3 item pernyataan yang diadopsi dari Budiarti (2012) dan Bukirom, et al., (2014) terkait dengan pendidikan kewirausahaan yang pernah dijalaninya, variabel dukungan akademik diukur menggunakan skala dari Autio, et al., (2001) dalam Gurbuz dan Aykol (2008) yang terdiri dari 4 item pernyataan dan akhirnya, untuk mengukur variabel niat kewirausahaan (entrepreneurial intention), responden diminta menentukan tingkat ketertarikan mereka untuk mendirikan usaha sendiri setelah mereka lulus sarjana dengan 3 item pernyataan yang diadopsi dari Gerry et al., (2008), yang menunjukkan tingkat intensi mereka untuk berwirausaha. Secara keseluruhan, untuk pendidikan kewirausahaan, dukungan akademik dan niat kewirausahaan, pernyataan diukur dengan menggunakan 5-point Likert scale, dimana responden diminta untuk menjawab dengan pilihan angka antara 1-5 (1= sangat tidak setuju, dan $5=$ sangat setuju).

Sebelum dilakukan pengujian hipotesis, dilakukan uji terhadap penyimpangan asumsi klasik yang meliputi: uji multikolinearitas, uji normalitas dan uji heterokesdastisitas. Hasil uji asumsi klasik menunjukkan data terdistribusi normal, tidak terjadi multikolinearitas dan heteroskedastisitas. Setelah itu dilanjutkan dengan pengujian hipotesis dengan menggunakan analisis regresi berganda.

Dalam penelitian ini regresi berganda digunakan untuk menguji variabel Pendidikan Kewirausahaan $\left(\mathrm{X}_{1}\right)$ dan Dukungan Akademik $\left(\mathrm{X}_{2}\right)$ sebagai variabel independen terhadap Niat Kewirausahaan Mahasiswa $\left(\mathrm{Y}_{1}\right)$ sebagai variabel dependen dengan menggunakan persamaan: $Y_{1}=b_{0}+b_{1} . X_{1}+$ $\mathrm{b}_{2} \mathrm{X}_{2}$, di mana $\mathrm{Y}_{1}$ niat kewirausahaan mahasiswa, $X_{1}$ pendidikan kewirausahaan, $X_{2}$ dukungan akademik, $\mathrm{b}_{0}$ konstanta, $\mathrm{b}_{1}, \mathrm{~b}_{2}$ koefisien regresi. 


\section{Published Oktober 2017 \\ JURNAL ILMIAH MANAJEMEN \& BISNIS \\ ISSN : 1693-7619 (print) | ISSN: 2580-4170 (online), http://jurnal.umsu.ac.id/index.php/mbisnis}

\section{HASIL DAN PEMBAHASAN \\ Hasil Penelitian}

Ringkasan Statistik Deskriptif dari masing-masing variabel terlihat dalam tabel di bawah :

Tabel 1. Statistik Deskriptif

\begin{tabular}{clcrc}
\hline No. & \multicolumn{1}{c}{ Variabel } & Mean & Std. Deviation & N \\
\hline 1 & Niat Kewirausahaan & 3.9556 & .73450 & 68 \\
2 & Pendidikan & 3.8221 & .96161 & 68 \\
& Kewirausahaan & & & \\
3 & Dukungan Akademik & 3.6507 & .71776 & 68 \\
\hline Sumber : Data primer, diolah (2016) & & &
\end{tabular}

Pada tabel 11 dapat dilihat bahwa total rata-rata skor tiap variabel di atas 3.00 . Hal ini menunjukkan bahwa niat kewirausahaan, pendidikan kewirausahaan dan dukungan akademik pada mahasiswa STIEPARI Semarang termasuk dalam kategori tinggi. Sebelum dilakukan analisis regresi, terlebih dahulu dilakukan uji validitas, uji reliabilitas dan uji asumsi klasik. Uji validitas dalam penelitian ini menggunakan analisis butir (item) yakni dengan melakukan korelasi skor setiap item dengan skor total yang merupakan jumlah tiap skor butir. Hasil perhitungan $r_{x y}$ dikonsultasikan pada tabel $r_{x y}$ dengan taraf signifikan 5\%, jika $r_{\text {hitung }}>r$ tabel maka butir angket dikatakan valid. Untuk uji reliabilitas, suatu variabel dianggap reliabel jika nilai cronbach alpha $>0.60$ (Ghozali, 2011).

Tabel 2. Hasil Uji Validitas dan Reliabilitas

\begin{tabular}{lcc}
\hline Variabel dan Indikator & r hitung & $\begin{array}{c}\text { Reliabilitas } \\
\text { (Cronbach Alpha) }\end{array}$ \\
\hline Pendidikan Kewirausahaan (X1) & & 0.853 \\
X1.1 & 0.886 & \\
X1.2 & 0.877 & \\
X1.3 & 0.878 & 0.782 \\
Dukungan Akademik (X2) & & \\
X2.1 & 0.750 & \\
X2.2 & 0,697 & \\
X2.3 & 0.805 & \\
X2.4 & 0,860 & \\
Intensi Kewirausahaan (Y) & & \\
Y1 & 0,796 & \\
Y2 & 0.802 & \\
Y3 & 0.822 & \\
Sumber: Data primer, diolah (2016) & &
\end{tabular}

Dari tabel 2 tampak bahwa semua instrumen variabel bernilai positif dan lebih besar dari $r$ tabel (0.235). Koefisien alpha dari semua variabel menunjukkan alpha di atas 


\section{Published Oktober 2017}

JURNAL ILMIAH MANAJEMEN \& BISNIS

ISSN : $1693-7619$ (print) | ISSN: 2580-4170 (online), http://jurnal.umsu.ac.id/index.php/mbisnis

0,6 . Ini berarti semua instrumen adalah valid dan reliabel dan dapat digunakan untuk proses pengolahan data selanjutnya.

Adapun hasil uji asumsi klasik yang meliputi uji normalitas, uji multikolinearitas, heteroskedastisitas menunjukkan data terdistribusi dengan normal, tidak terjadi multikolinearitas dan heteroskedastisitas.

Hasil analisis regresi berganda pengaruh pendidikan kewirausahaan dan dukungan akademik terhadap niat kewirausahaan mahasiswa disajikan dalam tabel berikut:

Tabel 3. Hasil Analisis Regresi

\begin{tabular}{|c|c|c|c|c|c|c|c|}
\hline Model & & $\begin{array}{c}\text { Koefisien } \\
\text { regresi }\end{array}$ & $\begin{array}{l}\text { Nilai } \\
\text { Uji t }\end{array}$ & Sig. & $\begin{array}{l}\text { Nilai } \\
\text { Uji F }\end{array}$ & Sig. & $\overline{R^{2}}$ \\
\hline $\begin{array}{l}\text { Konstanta } \\
\text { Pddk_Kewrushn }\left(\mathrm{X}_{1}\right) \rightarrow \\
\text { (Y) }\end{array}$ & Niat_Kwrushn & $\begin{array}{l}.857 \\
.372\end{array}$ & $\begin{array}{l}3.301 \\
5.725\end{array}$ & $\begin{array}{l}.002 \\
.000\end{array}$ & 79.524 & $.000^{\mathrm{a}}$ & .710 \\
\hline $\begin{array}{l}\text { Duk_Akademik }\left(\mathrm{X}_{2}\right) \rightarrow \\
(\mathrm{Y})\end{array}$ & Niat_Kwrushn & .459. & 5.271 & .000 & & & \\
\hline
\end{tabular}

Sumber : Data primer, diolah (2016)

Analisis koefisien determinasi dilakukan untuk melihat pengaruh pendidikan kewirausahaan $\left(\mathrm{X}_{1}\right)$ dan dukungan akademik $\left(\mathrm{X}_{2}\right)$ terhadap niat kewirausahaan mahasiswa $\left(\mathrm{Y}_{1}\right)$. Dari tabel 3 terlihat besarnya koefisien determinasi $R^{2}=0,710$, hal ini menunjukkan bahwa $71 \%$ niat kewirausahaan mahasiswa dipengaruhi oleh pendidikan kewirausahaan dan dukungan akademik, sisanya 29\% dipengaruhi oleh variabel lain.

Lebih lanjut pengaruh kausal empiris antara variabel pendidikan kewirausahaan $\left(\mathrm{X}_{1}\right)$ dan dukungan akademik $\left(\mathrm{X}_{2}\right)$ terhadap niat kewirausahaan mahasiswa $\left(\mathrm{Y}_{1}\right)$ dapat digambarkan dalam persamaan regresi: $\mathrm{Y}_{1}=$ $0,857+0,372 X_{1}+0,459 X_{2}$. Artinya bahwa jika tidak ada variabel independen pendidikan kewirausahaan dan dukungan akademik, maka besarnya niat kewirausahaan mahasiswa adalah 0,857. Koefisien regresi sebesar 0,372 pendidikan kewirausahaan terhadap niat kewirausahaan mahasiswa adalah positif yang artinya setiap peningkatan dalam variabel pendidikan kewirausahaan sebesar $100 \%$ akan meningkatkan niat kewirausahaan mahasiswa sebesar $37,2 \%$. Adapun nilai t hitung sebesar $5,725>\mathrm{t}$ tabel $(\mathrm{df}=65)$ sebesar 1,997 dan signifikansi 0,000 menunjukkan bahwa pendidikan kewirausahaan berpengaruh secara signifikan terhadap niat kewirausahaan mahasiswa, dengan demikian hipotesis 1 dapat diterima.

Koefisien regresi sebesar 0,459 menunjukkan dukungan akademik berpengaruh positif terhadap niat kewirausahaan mahasiswa, yang artinya setiap peningkatan dalam variabel dukungan akademik sebesar $100 \%$ akan meningkatkan niat kewirausahaan mahasiswa sebesar $48,8 \%$. Adapun nilai t hitung sebesar 5.271 > t tabel ( df = 65) sebesar 1,997 dan signifikansi 0,000 menunjukkan bahwa dukungan akademik berpengaruh secara signifikan terhadap niat kewirausahaan mahasiswa, dengan demikian hipotesis 2 dapat diterima.

Dari uji Anova didapatkan $\mathrm{F}$ hitung sebesar $79.524>\mathrm{F}$ tabel sebesar 3,13 dengan tingkat signifikansi 0,000 yang berarti 
kontribusi variabel pendidikan kewirausahaan dan dukungan akademik signifikan dalam memprediksi nilai variabel niat kewirausahaan mahasiswa. Dengan demikian hipotesis 3 dapat diterima.

\section{Pembahasan}

Hasil penelitian ini menyatakan pendidikan kewirausahaan berpengaruh positif dan signifikan terhadap niat kewirausahaaan mahasiswa. Penelitian ini mendukung pendapat Noel (1998), Wilson, et al. (2007) dan Lestari dan Wijaya (2012) yang menyatakan bahwa pendidikan kewirausahaan berpengaruh secara signifikan terhadap minat berwirausaha.

Hal ini menunjukkan bahwa pendidikan kewirausahaan merupakan variabel explanatory yang berguna di Indonesia. Lembaga pendidikan di Indonesia dapat mempertimbangkan pendidikan kewirausahaan sebagai bagian dari satu set kriteria yang lebih luas untuk dalam mendidik dan memberikan kemampuan wirausaha kepada para lulusannya dan memberikan motivasi untuk berani memilih berwirausaha sebagai karir mereka. Pihak perguruan tinggi perlu menerapkan pola pembelajaran kewirausahaan yang kongkrit berdasar masukan empiris untuk membekali mahasiswa dengan pengetahuan yang bermakna agar dapat mendorong semangat mahasiswa untuk berwirausaha. Hal penting yang perlu diperhatikan di sini, bahwa pendidikan kewirausahaan mampu memberikan pengetahuan yang berhubungan erat dengan kewirausahaan; memperoleh ketrampilan dalam menggunakan teknik, analisis situasi usaha, dan menyusun rencana kerja; mengidentifikasi motivasi, potensi, bakat dan ketrampilan kewirausahaan dan megembangkannya; menghilangkan resiko yang terdapat di dalam teknik analisis; mengembangkan empati dan dukungan bagi aspek unik dalam kewirausahaan; merubah sikap dan pemikiran yang salah terhadap perubahan; mendorong munculnya usaha baru; dan menstimulasi elemen sosialisasi afektif. Dengan demikian pendidikan kewirausahaan diharapkan mampu mendorong niat kewirausahaan mahasiswa. Hal ini sejalan dengan hasil penelitian Kourilsky dan Walstad (1998) maupun Gerry et al., (2008) yang menyatakan bahwa pembekalan pendidikan kewirausahaan pada seseorang sejak usia dini dapat meningkatkan potensi seseorang untuk menjadi wirausahawan. Bukirom et al., (2014) juga menemukan bahwa pendidikan kewirausahaan berpengaruh secara positif dan signifikan terhadap pembentukan jiwa kewirausahaan mahasiswa. Fatoki (2014) berpendapat pendidikan kewirausahaan menjadi faktor terpenting dalam menumbuhkan dan mengembangkan keinginan, jiwa dan perilaku berwirausaha dikalangan genarasi muda karena pendidikan merupakan sumber sikap dan niat keseluruhan untuk menjadi wirausahawan.

Penelitian ini juga membuktikan dukungan akademik berpengaruh positif dan signifikan terhadap niat kewirausahaan mahasiswa, hal ini mendukung pendapat Indarti (2004), yang menyatakan bahwa perguruan tinggi sebagai penyelenggara pendidikan kewirausahaan, dapat juga merupakan lingkungan yang dapat mempengaruhi intensi berwirausaha pada mahasiswa. Kenyataan menunjukkan bahwa dukungan akademik yang tinggi dapat menyebabkan mahasiswa makin tinggi niatnya untuk berwirausaha. Dengan demikian hasil penelitian ini juga mendukung hasil penelitian Rasheed (2000), Galloway, Kelly dan Keogh (2006), serta Suharti dan Sirene (2011) yang menemukan bahwa dukungan 


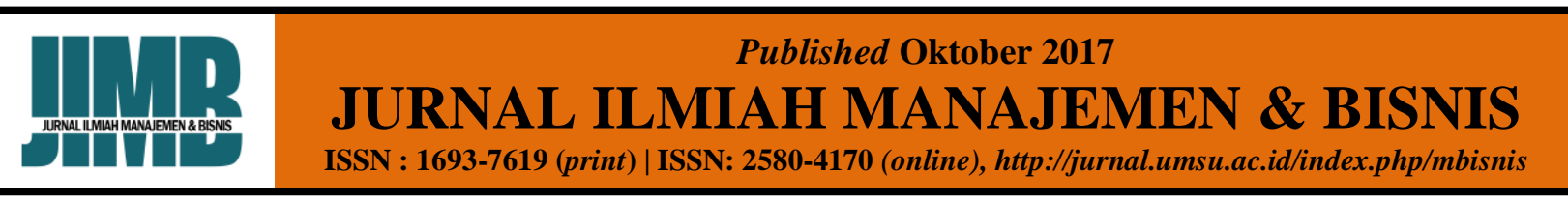

akademik perbengaruh positif terhadap niat kewirausahaan mahasiswa. Penelitian dari Wiyanto (2015) juga menyatakan bahwa dukungan akademik mempunyai pengaruh yang signifikan terhadap niat berwirausaha mahasiswa.

Hasil penelitian ini memperkuat pentingnya dukungan bagi mahasiswa di lingkungan perguruan tinggi. Kenyataan menunjukkan bahwa dukungan akademik yang tinggi dapat menumbuhkan motivasi berwirausaha yang efektif di kalangan mahasiswa sehingga diharapkan dapat mendorong munculnya lulusan yang memilih karir sebagai entrepreneur dan dalam jangka panjang diharapkan akan dapat memecahkan permasalahan ketenagakerjaan di Indonesia.

Secara simultan, hasil penelitian menunjukkan bahwa perpaduan antara pendidikan kewirausahaan dan dukungan akademik secara bersama-sama signifikan mempengaruhi niat kewirausahaan mahasiswa. Jadi jika Perguruan Tinggi mengupayakan pendidikan kewirausahaan yang diberikan berkualitas disertai dukungan akademik yang cukup baik, maka diharapkan niat kewirausahaan mahasiswa akan mengalami peningkatan yang cukup signifikan, sehingga dapat mendorong munculnya lulusan yang memilih karir sebagai entrepreneur. Dengan demikian akan sangat membantu mengurangi beban pemerintah dalam hal mengatasi pengangguran.

\section{SIMPULAN}

Berdasarkan hasil penelitian yang diperoleh, maka terdapat beberapa hal yang dapat disimpulkan dalam penelitian ini sesuai dengan tujuan yang telah ditetapkan, yaitu terbukti bahwa pendidikan kewirausahaan dan dukungan akademik berpengaruh positif dan signifikan terhadap niat kewirausahaan mahasiswa, baik secara parsial maupun secara simultan. Hasil penelitian ini memiliki implikasi praktis dengan temuan bahwa pendidikan kewirausahaan merupakan variabel explanatory yang berguna di Indonesia. Lembaga pendidikan di Indonesia dapat mempertimbangkan pendidikan kewirausahaan sebagai bagian dari satu set kriteria yang lebih luas untuk dalam mendidik dan memberikan kemampuan wirausaha kepada para lulusannya dan memberikan motivasi untuk berani memilih berwirausaha sebagai karir mereka. Hasil penelitian ini juga memperkuat pentingnya dukungan bagi mahasiswa di lingkungan perguruan tinggi. Kenyataan menunjukkan bahwa dukungan akademik yang tinggi dapat menumbuhkan motivasi berwirausaha yang efektif di kalangan mahasiswa sehingga diharapkan dapat mendorong munculnya lulusan yang memilih karir sebagai entrepreneur dan dalam jangka panjang diharapkan akan dapat memecahkan permasalahan ketenagakerjaan di Indonesia. Penelitian yang dilakukan ini masih memiliki kelemahan dikarenakan adanya beberapa keterbatasan, antara lain karena penelitian ini hanya dilakukan pada lokasi penelitian yang terbatas, yaitu mahasiswa STIEPARI Semarang. Meskipun responden berasal dari berbagai latar belakang yang berbeda, namun ada keterbatasan untuk menggeneralisasi hasil penelitian ini dan harus diinterpretasikan secara hati-hati. Oleh karena itu ada beberapa pengembangan yang dapat dilakukan dalam penelitian-penelitian selanjutnya antara lain masih perlu dilakukan penelitian pada aspek yang sama pada sampel yang berbeda untuk mengetahui konsistensi hasil penelitian ini. Selain itu dapat dilakukan uji ulang penelitian ini dengan menambahkan variabel-variabel lain yang berpengaruh dan belum digunakan dalam penelitian ini atau dengan menggunakan metode yang berbeda 


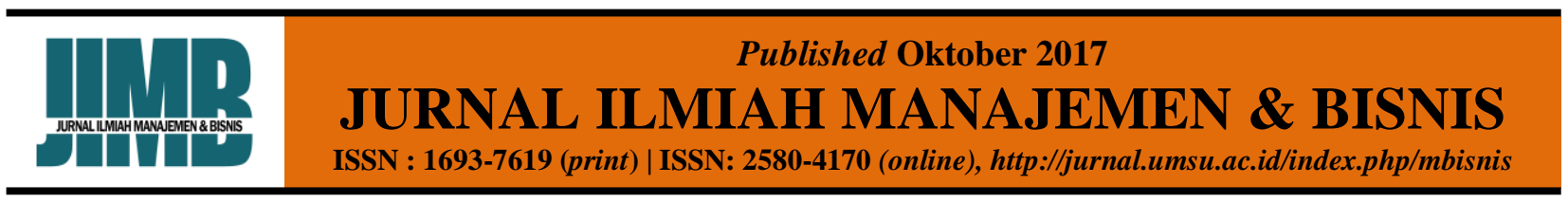

untuk memperoleh pemahaman yang lebih baik dan hasil yang lebih akurat. Selain itu penelitian ini hanya meneliti niat kewirausahaan mahasiswa. Untuk melengkapi Theory of Planned Behavior, disarankan penelitian mendatang diarahkan meneliti sampai perilaku riil mahasiswa dalam berwirausaha, sehingga diperoleh kerangka model yang lengkap.

\section{REFERENSI}

Alwisol. (2009). Psikologi Kepribadian, Edisi Revisi. Malang: UMM Pres.

Autio, E., Keely, R., Klofsten, M., Parker, G., dan Hay, M. (2001). Entrepreneurial Intent Among Students in Scandinaviaand in the USA, Enterprise and Innovation Management Studies. 2(2), 145-160.

Budiarti, Marlina. (2012). Analisis pengaruh pendidikan kewirausahaan terhadap niat kewirausahan mahasiswa (studi kasus pada mahasiswa program ekstensi fakultas ekonomi universitas Indonesia). Skripsi. Jurusan Manajemen Fakultas Ekonomi Universitas Indonesia. Salemba.

Bukirom, Haryo Indradi, Andi Permana, dan Martono. (2014). Pengaruh Pendidikan Berwirausaha dan Motivasi Berwirausaha terhadap Pembentukan Jiwa Berwirausaha Mahasiswa, Media Ekonomi dan Manajemen, 29(20), 144152.

Choo, S., dan M. Wong. (2006). Entrepreneurial Intention: Triggers and Barriers to New Venture Creations inSingapore. Singapore Management Review, 28(2), 47-64.

Dani A. (2014). Sarjana Pengangguran? Apa Penyebabnya?.

https://www.kompasianacom/dani_abas/ sarjana-pengangguran-apa- penyebabnya_54f922e3a33311ef048b 46e8. Diakses 8 Juni 2015.

Fatoki, Olawale. (2014). The Entrepreneurial Intention of Undergraduate Students in South Africa: The Influences of Entrepreneurship Education and Previous Work Experience. Mediterranean Journal of Social Sciences, 5(7), 294-299.

Galloway. L, Kelly.S. dan Keogh.W. (2006). Identifying Entrepreneurial Potential in Students.Working Paper No. 006, National Council for Graduate Entrepreneurship.

Gerry. C, Susana. C. dan Nogueira.F. (2008). Tracking Student Entrepreneurial Potential: Personal Attributes and the Propensity for Business Start-Ups after Graduation in a Portuguese University. International Research Journal Problems and Perspectives in Management, 6(4), 45-53.

Ghozali, Imam. (2011). Aplikasi Analisis Multivariate Dengan Program SPSS. Edisi 5. Semarang : BP Universitas Diponegoro

Gurbuz, G. dan Aykol, S. (2008). Entrepreneurial Intentions of Young Educated Public in Turkey. Journal of Global Strategic Management, 4(1), 4756.

Indarti, N., (2004). Factors Affecting Entrepreneurial Intentions Among Indonesian Students. Jurnal Ekonomi dan Bisnis, 19(1), 57-70.

Kalla, M.Y. (2011). Kemajuan Bangsa, Pendidikan dan Kewirausahaan. Pidato Ilmiah pada penganugrahan gelar Doktor Honoris Causa. Universitas Pendidikan Indonesia, 17 Maret 2011.

Kourilsky, M.L. dan Walstad, W.B. (1998). Entrepreneurship and Female Youth: Knowledge, Attitudes, Gender 
Differences and Educational Practices. Journal of Business Venturing, 13(1), 77-88.

Krueger, N. (1993). The Impact of Prior Entrepreneurial Exposure on Perceptions of New Venture Feasibility and Desirability. Entrepreneurial Theory Practice, 18(1), 5-21.

Krueger, N. F., Reilly, M.,dan Carsrud, A. (2000). Competing Models of Entrepreneurial Intentions. Journal of Business Venturing, 15(5/6), 411-432.

Lee, S.H. dan Wong, P.K. (2004). An Exploratory Study of Technopreneurial Intentions: A Career Anchor Perspective. Journal of Business Venturing, 19(1), 7-28.

Lestari, Retno B. dan Wijaya, Trisnadi.(2012). Pengaruh Pendidikan Kewirausahaan Terhadap Minat Berwirausaha Mahasiswa di STIE MDP, STMIK MDP, dan STIE MUSI. Forum Bisnis Dan Kewirausahaan Jurnal Ilmiah STIE MDP. 1(2), 112-119.

Listyaningsih, U. dan Kiswanto, E. (2009). Bantuan Langsung Tunai Mengatasi Masalah dengan Masalah. Populasi, 19 (1), 13-26.

Narzudin, A. M., Ahmad, N. H., dan Lin, C. E. (2009). Examining a Model of Entrepreneurial Intention Among Malaysian Using SEM Procedure. European Journal of Scientific Research. 33(2), 365-373

Nasrun, M. A., 2010. Mengapa Banyak Sarjana yang Menganggur? Suara Merdeka,25 September.

Noel, T. (1998). Effects of Entrepreneurial Education on Intent to Open a Business: An Exploratory Study. Journal of Entrepreneurship Education, 5, 3-13.

Nursito, S. dan Nugroho A, J, S. (2013). Analisis Pengaruh Interaksi
Pengetahuan Kewirausahaan Dan Efikasi Diri Terhadap Intensi Kewirausahaan. Jurnal Kiat BISNIS, $5(2)$.

Peraturan Pemerintah Republik Indonesia Nomor 60 Tahun 1999 Pendidikan Tinggi. 24 Juni 1999. Lembaran Negara Republik Indonesia Tahun 1999 Nomor 155. Jakarta

Rasheed, H.S. (2000). Developing Entrepreneurial Potential in Youth: The Effects of Entrepreneurial Education and Venture Creation, (http://USASEB2001 proceedings063, diakses 25 Mei 2014).

Rasli, Amran., Khan, S.U.R., Malekifar, S dan Samrena Jabeen. 2013. Factors Affecting Entrepreneurial Intention Among Graduate Students of Universiti Teknologi Malaysia. International Journal of Business and Social Science, 4(2), 182-188.

Suharti, Lieli dan Sirine, H. (2011). FaktorFaktor yang Berpengaruh Terhadap Niat Kewirausahaan (Entrepreneurial Intention) (Studi Terhadap Mahasiswa Universitas Kristen Satya Wacana, Salatiga). Jurnal Manajemen dan Kewirausahaan, 13(2), 124-134

Suryana. (2006). Kewirausahaan : Pedoman Praktis : Kiat dan Proses Menuju Sukses. Jakarta: Salemba Empat.

Wilson, F., J. Kickul, dan D. Marlino. (2007). Gender, Entrepreneurial Self-efficacy, and Entrepreneurial Career Intentions: Implications of Entrepreneurship Education. Entrepreneurship: Theory and Practice, 31(3), 387- 406.

Wiyanto, H. (2015). Dukungan Akademik dan Dukungan Sosial sebagai Prediktor Niat Berwirausaha Mahasiswa (Studi Pada Mahasiswa Peminatan Kewirausahaan Program Studi S1 Manajemen Fakultas 


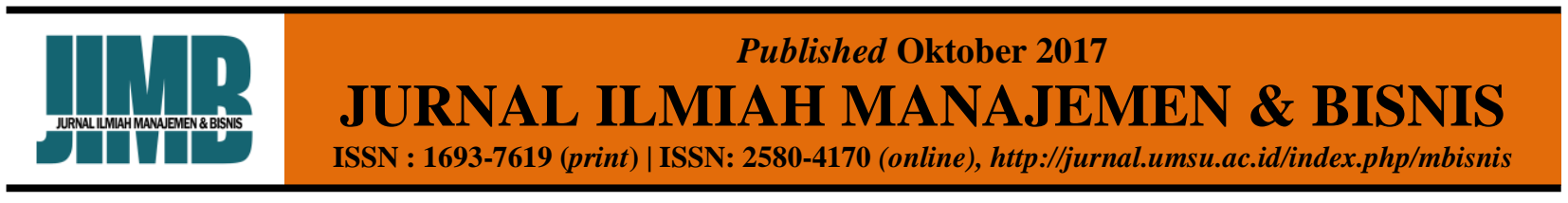

Ekonomi Universitas Tarumanagara). Jurnal Manajemen, 19(3), 374-386

$\mathrm{Wu}, \mathrm{S}$. dan Wu, L. (2008). The Impact of Higher Education on Entrepreneurial Intentions of University Students in China. Journal of Small Business and Enterprise Development, 15(4), 752774.

Yohnson. (2003). Peranan Universitas dalam Memotivasi Sarjana Menjadi Young Entrepreneurs. Jurnal Manajemen dan Kewirausahaan, 5(2), 97-111. 